\title{
Efficacy and cost-effectiveness of the cell saver system in instrumented posterior fusion with thoracic and lumbar vertebral fractures
}

\author{
[D Serdar Hakan Başaran, M.D., ${ }^{1}$ ๑ Alkan Bayrak, M.D., ${ }^{1}$ ¿ Emrah Sayit, M.D., ${ }^{2}$ \\ ๑ Halil Nadir Öneş, M.D., ${ }^{1} \odot$ Kadir Gözügöl, M.D., ${ }^{3} \odot$ Cemal Kural, M.D. ${ }^{1}$
}

\begin{abstract}
1Department of Orthopaedics and Traumatology, Bakırköy Dr. Sadi Konuk Training and Research Hospital, İstanbul-Turkey ${ }^{2}$ Department of Orthopaedics and Traumatology, Samsun Training and Research Hospital, Samsun-Turkey

${ }^{3}$ Department of Orthopaedics and Traumatology, Istanbul University Cerrahpaşa Faculty of Medicine, İstanbul-Turkey
\end{abstract}

\begin{abstract}
BACKGROUND: The aim of our study was to determine the efficacy and cost-effectiveness of intraoperative autotransfusion that uses the cell saver system (CSS) in patients undergoing posterior instrumentation and fusion of thoracic and lumbar vertebral fractures.

METHODS: We divided $12 \mathrm{I}$ patients who were to undergo posterior instrumentation and fusion due to thoracic and lumbar vertebral fractures into two groups: 59 patients ( 23 males and 36 females) were in the cell saver group, and 62 patients ( 22 males and 40 females) were in the control group. Hemoglobin, hematocrit, and red blood cell (RBC) values were recorded for all patients preoperatively, on the postoperative first, second, and third days, and on the hospital discharge day. Transfusion rates and numbers of allogeneic erythrocyte transfusions, as well as the costs of transfused total auto- and allogeneic transfusions were compared.
\end{abstract}

RESULTS: The numbers of erythrocyte suspensions transfused perioperatively were $0.2 \pm 0.6$ units in the cell saver group and $0.7 \pm 1.4$ units in the control group $(p=0.01)$. Statistically significant differences were noted between the two groups on the postoperative first, second, and third days in terms of hemoglobin, hematocrit, and RBC values. These differences had disappeared by the hospital discharge day. The average cost of perioperative blood transfusions was $\$ 431 \pm 27.4$ in the cell saver group and $\$ 34.5 \pm 66.25$ in the control group $(p<0.001)$.

CONCLUSION: The use of the CSS was not cost-effective, but it was particularly successful at reducing the rate and the number of units of postoperative allogenic blood transfusions.

Keywords: Blood transfusion; cell saver system; cost effectiveness; spinal surgery.

\section{INTRODUCTION}

Intraoperative blood loss is a common problem, especially in the procedures of multi-level posterior instrumentation and spinal fusion. ${ }^{[I]}$ Consequently, major spinal surgery procedures usually require allogeneic erythrocytes transfusions (AETs) during and after the operation. ${ }^{[2]}$ Despite the availability of modern screening methods, AETs still carry a risk of infectious diseases such as HIV, CMV, and hepatitis. ${ }^{[3,4]}$ More- over, AETs may cause allergic reactions, graft versus host disease, isoimmunization, and hemolytic reactions. ${ }^{[5]}$

Alternative methods have been developed to obtain safer
blood loss management in major spinal surgery procedures
because of these risks. These include controlled hypotensive
anesthesia, the use of patient positioning devices to reduce
abdominal compression, provision of acute normovolemic
hemodilution, the use of topical hemostatic agents, pharma-

Cite this article as: Başaran SH, Bayrak A, Sayit E, Öneş HN, Gözügöl K, Kural C. Efficacy and cost-effectiveness of the cell saver system in instrumented posterior fusion with thoracic and lumbar vertebral fractures. Ulus Travma Acil Cerrahi Derg 2019;25:66-70.

Address for correspondence: Serdar Hakan Başaran, M.D.

Adres bilgisi: Bakırköy Dr. Sadi Konuk Eğitim ve Araştırma Hastanesi, Ortopedi ve Travmatoloji Kliniği, İstanbul, Turkey.

Tel: +90 212 - 4147170 E-mail: drserdarhakan@gmail.com

Ulus Travma Acil Cerrahi Derg 2019;25(I):66-70 DOI: 10.5505/tites.2018.77823 Submitted: 24.01.2018 Accepted: 14.08.2018 Online: 27.12.2018

Copyright 2019 Turkish Association of Trauma and Emergency Surgery 
cologic stimulation of erythropoiesis, preoperative autologous blood donation, and intraoperative and/or postoperative CSS-mediated autotransfusion, which can all reduce the AET requirements during and after major spinal surgery. ${ }^{[1,3,6-9]}$ Intraoperative use of the CSS reduces the need for AETs; thus, this system may prevent AET complications. ${ }^{[10-1 I]}$

The purpose of present study was to determine the efficacy and cost-effectiveness of intraoperative autotransfusion using the CSS in patients undergoing posterior instrumentation and fusion for the treatment of thoracic and lumbar vertebral fractures.

\section{MATERIALS AND METHODS}

Approval for the study was granted by the Local Ethics Committee. The patients who underwent posterior instrumentation and fusion due to thoracic and lumbar vertebral fractures were reviewed retrospectively. An intraoperative autotransfusion system was used in operations due to surgeons' demand and randomly. Patients older than 18 years and who had no previous spinal surgery were included. Those without full medical records or who underwent procedures including anterior approach and laminectomy were excluded. Patients who had coagulopathy, postoperative myocardial infarction, pulmonary embolism, or gastrointestinal bleeding and who had different surgery due to any fracture were also excluded. In total, 121 patients were divided into two groups: 59 patients ( 23 males and 36 females) were in the cell saver group, and 62 patients ( 22 males and 40 females) were in the control group. All surgeries were performed by the same surgeons. Demographic features of the patients are given in Table I. The AutoLog Autotransfusion System (Medtronic, USA) was used intraoperatively in the cell saver group, but this system was not continued postoperatively. Perioperative blood loss management was performed for both groups.

All surgical procedures were performed under hypotensive anesthesia and intraoperative hemodilution. The iliac crest graft was not harvested in any patients. A hemovac drain with a positive pressure set to continuous suction was used in all patients, and the postoperative blood loss values were recorded. Low-molecular-weight heparin and anti-thromboembolic stockings were used for the prophylaxis of deep vein thrombosis. Our indications for AET were hemoglobin $<8 \mathrm{mg} / \mathrm{dl}$ with tachycardia and hypotension. The intraoperative and postoperative numbers of transfused allogeneic erythrocyte suspension units were recorded. The costs of the CSS and the AET were also recorded in both groups. No major complications were observed in any patient.

The hemoglobin, hematocrit, and red blood cell (RBC) values were recorded preoperatively, then again on the postoperative first, second, and third days, and on the day of hospital discharge. The cell saver group was compared with the control group. We also analyzed the costs of both transfusion strategies.

The SPSS software (SPSS 20.0 for Macintosh, SPSS, Chicago, IL) was used for the statistical analysis. The data were evaluated with descriptive statistical methods (mean \pm standard deviation). An independent samples t-test was used for the analysis of independent groups of quantitative data showing normal distribution. A crude analysis of independent groups of qualitative data was obtained with the chi-square test. A $95 \%$ confidence interval and significance at $p<0.05$ were accepted.

\section{RESULTS}

No statistically significant differences were noted with regard to age, gender, body mass index, fusion levels, surgical duration, or intraoperative and postoperative bleeding between the two groups (Table I). The intraoperative bleeding amount was $553.7 \pm 393.7 \mathrm{ml}$ in the cell saver group and $479.7 \pm 166.3 \mathrm{ml}$ in the control group; postoperative bleeding was $292.8 \pm 135.1 \mathrm{ml}$ in the cell saver group and $284.2 \pm$ I 46.8 $\mathrm{ml}$ in the control group. No statistical difference was found between the two groups ( $p>0.05)$.

The two groups were also similar in terms of preoperative hemoglobin, hematocrit, and RBC values. However, statistically significant differences were noted between the two groups on the postoperative first, second, and third days in terms of the hemoglobin, hematocrit, and RBC values. These differences had disappeared by the hospital discharge day (Table 2).

Table I. Clinical characteristics of the patient groups

\begin{tabular}{lccc}
\hline & Cell saver group $(\mathbf{n = 5 9 )}$ & Control group $(\mathbf{n = 6 2})$ & $\mathbf{p}$ \\
\hline Gender (male/female) & $23 / 36$ & $22 / 40$ & 0.691 \\
Age (year) & $42.9 \pm 14.6$ & $38.6 \pm 14.7$ & 0.113 \\
Body mass index & $25.6 \pm 3.2$ & $25.7 \pm 3.1$ & 0.880 \\
Surgical duration (minute) & $153.1 \pm 69.4$ & $141.3 \pm 53.1$ & 0.293 \\
Levels of fusion & $3.6 \pm 1.4$ & $3.7 \pm 1.4$ & 0.739 \\
Intraoperative bleeding $(\mathrm{mL})$ & $553.7 \pm 393.7$ & $479.7 \pm 166.3$ & 0.177 \\
Postoperative bleeding $(\mathrm{mL})$ & $292.8 \pm 135.1$ & $284.2 \pm 146.8$ & 0.738 \\
\hline
\end{tabular}


We compared the averages of transfused allogeneic erythrocyte suspension units intraoperatively, postoperatively, and perioperatively in both groups (Table 3 ). We also compared the rates and numbers of patients transfused with allogeneic erythrocyte suspensions in both groups (Table 4).
The average cost of perioperative blood transfusions was $\$ 43 \mathrm{I} \pm 27.4$ (distribution, $\$ 42 \mathrm{I}-560.5$ ) in the cell saver group and $\$ 34.5 \pm 66.25$ (distribution, $\$ 0-279$ ) in the control group. The average cost of the perioperative blood transfusions was significantly higher for the cell saver group than for the con-

Table 2. Comparison of the hemoglobin, hematocrit, and red blood cell values for the cell saver and control groups

\begin{tabular}{|c|c|c|c|}
\hline & Cell saver group $(n=59)$ & Control group $(n=62)$ & $\mathbf{p}$ \\
\hline \multicolumn{4}{|l|}{ Preoperative } \\
\hline Hemoglobin & $12.6 \pm 1.8$ & $12.6 \pm 2$ & 0.904 \\
\hline Hematocrit & $38.3 \pm 4.8$ & $37 \pm 5.7$ & 0.193 \\
\hline $\mathrm{Rbc}$ & $4.5 \pm 0.8$ & $4.2 \pm 0.7$ & 0.077 \\
\hline \multicolumn{4}{|l|}{ Postoperative day I } \\
\hline Hemoglobin & $11.3 \pm 1.8$ & $10.5 \pm 1.7$ & 0.009 \\
\hline Hematocrit & $34.3 \pm 5.2$ & $31.4 \pm 5.4$ & 0.002 \\
\hline Red blood cell & $3.9 \pm 0.7$ & $3.6 \pm 0.7$ & 0.006 \\
\hline \multicolumn{4}{|l|}{ Postoperative day 2} \\
\hline Hemoglobin & $10.7 \pm 1.6$ & $10 \pm 1.7$ & 0.025 \\
\hline Hematocrit & $32.2 \pm 4.6$ & $29.9 \pm 5.4$ & 0.012 \\
\hline Red blood cell & $3.7 \pm 0.6$ & $3.4 \pm 0.6$ & 0.009 \\
\hline \multicolumn{4}{|l|}{ Postoperative day 3} \\
\hline Hemoglobin & $10.4 \pm 2.2$ & $9.6 \pm 1.4$ & 0.041 \\
\hline Hematocrit & $31.5 \pm 6.2$ & $28.5 \pm 4.3$ & 0.007 \\
\hline Red blood cell & $3.6 \pm 0.8$ & $3.3 \pm 0.6$ & 0.014 \\
\hline \multicolumn{4}{|l|}{ Discharge day } \\
\hline Hemoglobin & $10.6 \pm 1.9$ & $10.3 \pm 1.2$ & 0.234 \\
\hline Hematocrit & $32.2 \pm 5.4$ & $30.5 \pm 4.6$ & 0.068 \\
\hline Red blood cell & $3.7 \pm 0.7$ & $3.5 \pm 0.5$ & 0.116 \\
\hline
\end{tabular}

Table 3. Average numbers of transfused allogeneic erythrocyte suspension units

\begin{tabular}{|c|c|c|c|}
\hline & Cell saver group $(n=59)$ & Control group $(n=62)$ & $\mathbf{p}$ \\
\hline & Mean $\pm S D$ (range) & Mean $\pm S D$ (range) & \\
\hline Intraoperative & $0.02 \pm 0.13(0-1)$ & $0.05 \pm 0.28(0-2)$ & 0.437 \\
\hline Postoperative & $0.2 \pm 0.5(0-2)$ & $0.7 \pm 1.3(0-5)$ & 0.007 \\
\hline Perioperative & $0.2 \pm 0.6(0-3)$ & $0.7 \pm 1.4(0-6)$ & 0.010 \\
\hline
\end{tabular}

Table 4. Rates and number of patients transfused with allogeneic erythrocyte suspensions

\begin{tabular}{|c|c|c|c|c|c|}
\hline & \multicolumn{2}{|c|}{ Cell saver group $(n=59)$} & \multicolumn{2}{|c|}{ Control group $(n=62)$} & \multirow[t]{2}{*}{$\mathbf{p}$} \\
\hline & Yes & No & Yes & No & \\
\hline Intraoperative & I (I.7\%) & $58(98.3 \%)$ & $2(3.2 \%)$ & $60(96.8 \%)$ & 1.000 \\
\hline Postoperative & $9(15.3 \%)$ & $50(84.7 \%)$ & $20(32.3 \%)$ & $42(67.7 \%)$ & 0.029 \\
\hline Perioperative & $9(15.3 \%)$ & $50(84.7 \%)$ & $20(32.3 \%)$ & $42(67.7 \%)$ & 0.029 \\
\hline
\end{tabular}


trol group $(p<0.00 \mathrm{I})$. The average cost was calculated based on the blood transfusion and hospital stay, and other parameters were same for both groups.

\section{DISCUSSION}

Perioperative blood loss still represents a common problem for spinal surgeons in posterior spinal fusion and instrumentation. ${ }^{[l]}$ Multi-level posterior spinal fusion procedures usually involve major blood loss, and these procedures increase the requirement for $\mathrm{AETs}{ }^{\left[{ }^{12]}\right.}$ The present study showed that the use of the CSS successfully reduced the rates and numbers of patients transfused with allogeneic erythrocyte suspensions, both postoperatively and perioperatively, but not intraoperatively. The CSS method also successfully decreased the numbers of allogeneic erythrocyte suspension units used postoperatively and perioperatively. These findings are not compatible with some studies in literature, ${ }^{[3,10,13,14]}$ but they agree with others. ${ }^{[1,16]}$

The findings of the present study also showed that the protection of the hemoglobin, hematocrit, and RBC values until hospital discharge was more successful in the CSS group than in the control group. The blood recovery rate using the CSS was $45.3 \%$, which compared favorably with the results of Reitman et al. ${ }^{[3]}$

Some authors have indicated that the intraoperative use of the CSS did not diminish the rates of AET in spinal surgery, despite predonated autologous blood transfusions. ${ }^{[2,3,17,18]}$ Our study, as well as that of Owens et al. ${ }^{[16]}$ also found no decrease in the intraoperative numbers of allogeneic erythrocyte suspension units with the use of the CSS, but this number did decrease postoperatively.

Determining which patients would benefit from the CSS use remains a controversial issue. The use of the CSS is suggested especially in multi-level posterior spinal surgery with an estimated prolonged surgery time and excessive blood loss. ${ }^{[10,16,19]}$ In addition, some authors have stated that even if this system reduces the AET requirements, it is not necessary, especially for single-level or double-level posterior lumbar fusion. ${ }^{[3,7,18]}$ Other authors have also stated that the AES requirements of many spinal surgery patients can be provided by predonated blood transfusions. ${ }^{[3,17]}$ Nevertheless, other researches have shown that the patients in which the CSS was not used generally had greater requirements for autologous and the allogeneic blood transfusions when compared to the patients in which the CSS was used. ${ }^{[3,13,17]}$

The cost-effectiveness of the CSS is another important issue. The CSS use is not cost-effective in many posterior spinal instrumentation and fusion procedures, ${ }^{[18,20]}$ as we also determined here. One important reason for the cost increase of the CSS is its fixed cost regardless of the amount of salvaged or transfused blood. However, the efficacy of this system can be increased by also using it in the postoperative period. [20] The advantage of the CSS is that it can be used safely along with other blood conservation techniques. ${ }^{[21]}$ This system also can be chosen for patients with traumatic vertebral fractures, because autologous blood donation cannot be reserved in these patients.

Most of the previous studies indicated that the rates and numbers of allogeneic erythrocyte suspensions may be affected by the CSS use, because the blood transfusions were performed by autotransfusion with intraoperative collected and predonated blood. ${ }^{[2,3,17,18]}$ In addition, preoperative autologous blood donation may cause a reduction in patient's preoperative hemoglobin, hematocrit, and RBC values. None of our patients was able to undergo preoperative autologous blood donation.

One strength of the present study is that it included an investigation of the efficiency and cost-effectiveness of the CSS in traumatic vertebral fractures, a feature that is absent from the current literature. A weakness of our study was its retrospective nature.

\section{Conclusion}

Intraoperative autotransfusion using the CSS is a safe and effective method for lumbar and thoracic vertebral fracture surgery by posterior instrumentation and fusion. In addition, this method successfully reduced the numbers of allogeneic erythrocytes a suspension unit required, especially postoperatively. This method was also successful in decreasing the postoperative rates and numbers of patients transfused with allogeneic erythrocyte suspensions. The major disadvantage of this system seems to be its cost. In light of our study, we suggest the use of the CSS for surgical treatment of acute vertebral fractures.

Informed consent: Informed consent was obtained from all individual participants included in the study.

Funding: The author(s) received no financial support for the research, authorship, and/or publication of this article.

Conflict of interest: None declared.

\section{REFERENCES}

1. Elgafy H, Bransford RJ, McGuire RA, Dettori JR, Fischer D. Blood loss in major spine surgery: are there effective measures to decrease massive hemorrhage in major spine fusion surgery? Spine (Phila $\mathrm{Pa} 1976$ ) 2010;35:S47-56. [CrossRef]

2. Gause PR, Siska PA, Westrick ER, Zavatsky J, Irrgang JJ, Kang JD. Efficacy of intraoperative cell saver in decreasing postoperative blood transfusions in instrumented posterior lumbar fusion patients. Spine (Phila $\mathrm{Pa}$ 1976) 2008;33:571-5. [CrossRef]

3. Reitman CA, Watters WC, Sassard WR. The Cell Saver in adult lumbar fusion surgery: a cost-benefit outcomes study. Spine (Phila Pa 1976) 
2004;29:1580-3. [CrossRef]

4. Sharma S, Sharma P, Tyler LN. Transfusion of blood and blood products: indications and complications. Am Fam Phys 2011;83:719-24.

5. Cha CW, Deible C, Muzzonigro T, Lopez-Plaza I, Vogt M, Kang JD. Allogeneic transfusion requirements after autologous donations in posterior lumbar surgeries. Spine (Phila Pa 1976) 2002;27:99-104. [CrossRef]

6. Bess RS, Lenke LG, Bridwell KH, Steger-May K, Hensley M. Wasting of preoperatively donated autologous blood in the surgical treatment of adolescent idiopathic scoliosis. Spine (Phila Pa 1976) 2006;31:2375-80.

7. Florentino-Pineda I, Blakemore LC, Thompson GH, Poe-Kochert C, Adler P, Tripi P. The Effect of epsilon-aminocaproic acid on perioperative blood loss in patients with idiopathic scoliosis undergoing posterior spinal fusion: a preliminary prospective study. Spine (Phila Pa 1976) 2001;26:1147-51. [CrossRef]

8. McNeill TW, DeWald RL, Kuo KN, Bennett EJ, Salem MR. Controlled hypotensive anesthesia in scoliosis surgery. J Bone Joint Surg Am 1974;56:1167-72. [CrossRef]

9. Relton JE, Hall JE. An operation frame for spinal fusion. A new apparatus designed to reduce haemorrhage during operation. J Bone Joint Surg Br 1967;49:327-32. [CrossRef]

10. Bowen RE, Gardner S, Scaduto AA, Eagan M, Beckstead J. Efficacy of intraoperative cell salvage systems in pediatric idiopathic scoliosis patients undergoing posterior spinal fusion with segmental spinal instrumentation. Spine (Phila Pa 1976). 2010;35:246-51. [CrossRef]

11. Carless PA, Henry DA, Moxey AJ, O'Connell D, Brown T, Fergusson DA. Cell salvage for minimising perioperative allogeneic blood transfusion. Cochrane Database Syst Rev 2010;4:CD001888. [CrossRef]

12. Guay J, Haig M, Lortie L, Guertin MC, Poitras B. Predicting blood loss in surgery for idiopathic scoliosis. Can J Anaesth 1994;41:775-81. [CrossRef]

13. Lennon RL, Hosking MP, Gray JR, Klassen RA, Popovsky MA, Warner
MA. The effects of intraoperative blood salvage and induced hypotension on transfusion requirements during spinal surgical procedures. Mayo Clin Proc 1987;62:1090-4. [CrossRef]

14. Savvidou C, Chatziioannou SN, Pilichou A, Pneumaticos SG. Efficacy and cost-effectiveness of cell saving blood autotransfusion in adult lumbar fusion. Transfus Med 2009;19:202-6. [CrossRef]

15. Ersen O, Ekıncı S, Bılgıc S, Kose O, Oguz E, Sehırlıoglu A. Posterior spinal fusion in adolescent idiopathic scoliosis with or without intraoperative cell salvage system: a retrospective comparison. Musculoskelet Surg 2012;96:107-10. [CrossRef]

16. Owens RK 2nd, Crawford CH 3rd, Djurasovic M, Canan CE, Burke LO, Bratcher KR, et al. Predictive factors for the use of autologous cell saver transfusion in lumbar spinal surgery. Spine (Phila Pa 1976) 2013;38:E217-22. [CrossRef]

17. Siller TA, Dickson JH, Erwin WD. Efficacy and cost considerations of intraoperative autologous transfusion in spinal fusion for idiopathic scoliosis with predeposited blood. Spine (Phila Pa 1976) 1996;21:848-52.

18. Canan CE, Myers JA, Owens RK, Crawford CH 3rd, Djurasovic M, Burke LO, et al. Blood salvage produces higher total blood product costs in single-level lumbar spine surgery. Spine (Phila Pa 1976) 2013;38:7038. [CrossRef]

19. Chanda A, Smith DR, Nanda A. Autotransfusion by cell saver technique in surgery of lumbar and thoracic spinal fusion with instrumentation. J Neurosurg 2002;96:298-303. [CrossRef]

20. Behrman MJ, Keim HA. Perioperative red blood cell salvage in spine surgery. A prospective analysis. Clin Orthop Relat Res 1992;278:51-7.

21. Joseph SA Jr, Berekashvili K, Mariller MM, Rivlin M, Sharma K, Casden $\mathrm{A}$, et al. Blood conservation techniques in spinal deformity surgery: a retrospective review of patients refusing blood transfusion. Spine (Phila Pa 1976) 2008;33:2310-5. [CrossRef]

\section{ORIJINAL ÇALIŞMA - ÖZET}

\section{Torakal ve lomber vertebra kırıklarında enstrümentasyon ve posterior füzyon uygulanmış} hastalarda maliyet ve hücre koruyucu sistemin etkinliği

\section{Dr. Serdar Hakan Başaran,, ${ }^{1}$ Dr. Alkan Bayrak, ${ }^{1}$ Dr. Emrah Sayit, ${ }^{2}$ Dr. Halil Nadir Öneş, ${ }^{1}$ Dr. Kadir Gözügöl, ${ }^{3}$ Dr. Cemal Kural ${ }^{1}$}

${ }^{1}$ Bakırköy Dr. Sadi Konuk Eğitim ve Araştırma Hastanei, Ortopedi ve Travmatoloji Kliniği, İstanbul

${ }^{2}$ Samsun Eğitim ve Araştırma Hastanesi, Ortopedi ve Travmatoloji Kliniği, Samsun

${ }^{3}$ istanbul Üniversitesi Cerrahpaşa Tıp Fakültesi, Ortopedi ve Travmatoloji Anabilim Dalı, İstanbul

AMAÇ: Çalışmamızın amacı torakal ve lomber vertebra kırıkları nedeniyle posterior enstrümantasyon ve füzyon yapılan ve ameliyatta ototransfüzyon yapılan hastalarda hücre koruyucu sistemin etkinliğini ve maliyet etkinliğini belirlemektir.

GEREÇ VE YÖNTEM: Torakal ve lomber vertebra kırıkları nedeniyle posteriyor enstrümentasyon ve füzyon uygulanmış 121 hasta iki guruba ay rıldı: 59 hasta (23 erkek ve 36 kadın) hücre koruyucu gurup, 62 hasta (22 erkek ve 40 kadın) kontrol gurubuna dahil edildi. Hastaların hemoglobin, hemotokrit ve kırmızı hücre sayısı (KHS) ameliyat öncesi ve sonrası birinci, ikinci, üçüncü gün ve taburculuk esnasındaki değerleri değerlendirildi. Transfüzyon oranları ve allojenik eritrosit transfüzyonlarının (AET'ler) yanı sıra, transfüzyona tabi tutulan toplam oto ve allojenik transfüzyonların maliyetleri karşılaştırıldı.

BULGULAR: Perioperatif kan transfüzyonu hücre koruyucu grupta $0.2 \pm 0.6$ ünite, kontrol grubunda $0.7 \pm I .4$ ünite olarak tespit edildi ( $p=0.0 \mathrm{I}$ ). Ameliyat sonrası birinci, ikinci ve üçüncü günde hemoglobin, hemotokrit ve KHS arasında istatistiksel olarak anlamlı fark tespit edildi. Taburculuk hemoglobin, hemotokrit ve KHS arasında anlamlı farklılık saptanmadı. Perioperatif kan transfüzyonu ortalama maliyeti hücre koruyucu grupta $\$ 431 \pm 27.4$, kontrol grubunda $\$ 34.5 \pm 66.25$ olarak belirlendi $(p<0.001)$.

TARTIŞMA: Hücre koruma sisteminin kullanımı maliyet açısından uygun değildi, ancak özellikle ameliyat sonrası allojenik kan transfüzyonlarının oranını ve sayısını azaltmada başarılıydı.

Anahtar sözcükler: Hücre koruyucu sistem; kan transfüzyonu; maliyet etkinliği; omurga cerrahisi.

Ulus Travma Acil Cerrahi Derg 2019;25(I):66-70 doi: 10.5505/tites.2018.77823 